\title{
BOOKS AVAILABLE FOR REVIEW
}

The following books are available for review. Requests should be addressed to: Book Review Editor, AUSLEGUNG, Department of Philosophy, University of Kansas, Lawrence, Kansas 66045.

Adorno, Theodor W. Critical Models: Interventions and Catchwords. Translated by Henry W. Pickford. New York: Cambridge University Press, 1998.

Adorno, Theodor W. Hegel: Three Studies. Translated by Shierry Weber Nicholsen. Cambridge, MA: The MIT Press, 1994.

Appelbaum, David. The Vision of Kamt. Rockport, MA: Element, 1995.

Armstrong, D. M. A World of States of Affairs. New York: Cambridge University Press, 1997.

Bataille, Georges. On Nietzsche. New York: Paragon Press, 1994.

Berofsky, Bernard. Liberation from Self: A Theory of Personal Autonomy. Cambridge: Cambridge University Press, 1995.

Blank, Robert H. and Andre L. Bonnicksen, eds. Medicine Unbound: The Human Body and the Limits of Medical Intervention. New York: Columbia University Press, 1994.

Bloom, Irene ed. Knowledge Painfully Acquired. New York: Columbia University Press, 1995.

Bloom, Irene and Joshua A. Fogel. Meetings of Minds: Intellectual and Religious Interaction in East Asian Traditions of Thonght. New York: Columbia University Press, 1997.

Bloor, David. Wittgenstein, Rules and Instituitions. New York: Routledge, 1997.

Boeder, Heribert. Seditions: Heidegger and the Limit of Modernity. Translated and edited by Brainard, Marcus. Albany: State University of New York Press, 1997. 
Bohrer, Karl H. Suddenness. New York: Columbia University Press, 1994.

Cooper, John M. Reason and Emotion. Princeton: Princeton University Press, 1999.

Currie, Gregory. Image and Mind: Film, Philosophy and Cognitive Science. Cambridge: Cambridge University Press, 1995.

Cutting, Gary. Pragmatic Liberalism and the Critique of Modernity. Cambridge, Cambridge University Press, 1999.

DeBellis, Mark. Music and Conceptualization. Cambridge, Cambridge University Press, 1995.

Deleuze, Gilles. Difference and Repetition. Translated by Paul Patton. New York: Columbia University Press, 1994.

Deleuze, Gilles. Negotiations. Translated by Martin Joughin. New York: Columbia University Press, 1995.

Deleuze, Gilles and Felix Guattari. What is Philosophy? Translated by Hugh Tomlinson and Graham Burchell. New York: Columbia, 1994.

Douglas, Mary and David Hull eds. How Classification Works: Neil Goodman Among the Social Sciences. New York: Columbia University Press, 1994.

Finkielkraut, Alain. The Defeat of the Mind. New York: Columbia University Press, 1995.

Fiumara, Gemma Corradi. The Other Side of Language: A Philosophy of Listening, 2d ed. London: Routledge, 1995.

Gallagher, Shaun, ed. Hegel, History and Interpretation. Albany: State University of New York Press, 1997.

Garber, Daniel and Michael Ayers, ed. The Cambridge History of Seventeenth Century Philosophy,Vols. I and II. Cambridge: The Press Syndicate of the University of Cambridge, 1998.

Gernet, Jacques. Buddhism in Chinese Society. New York: Columbia University Press, 1995. 
Geuss, Raymond. Morality, Culture and History: Essays on German Philosophy. Cambridge: Cambridge University Press, 1999.

Gewirth, Alan. Self-Fulfillment. Princeton: Princeton University Press, 1998.

Gramsci, Antonio. Prison Notebooks, Volume II. Translated and edited by Joseph A. Buttigieg. New York: Columbia University Press, 1996.

Gress, David. From Plato to NATO. New York: The Free Press, 1998.

Gupta, Anil and Belnap Nuel. The Revision Theory of Truth. Cambridge: The MIT Press, 1993.

Hegel, G.W.F. Selections from Hegel's Phenomenology of Spirit. Translated by Howard P. Kainz. University Park: The Pennsylvania State University Press, 1994.

Heidegger, Martin. The Fundamental Concepts of Metaphysics. Translated by William McNeill and Nicholas Walker. Bloomington: IndianaUniversity Press, 1996.

Heidegger, Martin. Plato's Sophist. Translated by Rojcewicz and Andre Schuwer. Bloomington: Indiana University Press, 1997.

Herman, Arthur. The Idea of the Decline in Western History. New York: The Free Press, 1997.

Howland, Jacob. The Republic: The Odyssey of Philosophy. New York: Twayne Publishers, 1994.

Hughes, G.E. and M.J. Cresswell. A New Introduction to Modal Logic. New York: Routledge, 1996.

Ingram, David. Reason, History, \& Politics: The Communitarian Grounds of Legitimation in the Modern Age. Albany: State University of New York Press, 1995.

Jones, Judith A. Intensity: An Essay in Whiteheadian Ontology. Nashville: Vanderbilt University Press, 1998. 
Kegley, Jacquelyn Ann K. Genuine Individuals and Gemuine Communities. Nashville: Vanderbilt University Press, 1997.

Leonardi Paolo and Marco Santambrogia, eds. On Quine: New Essays. New York: Cambridge University Press, 1995.

Levi, Isaac. For the Sake of Argument: Ramsey Test Conditionals, Inductive Inference, and Nonmonotonic Reasoning. Cambridge: Cambridge University Press, 1996.

Levinas, Emmanuel. Entre Nous: Thinking-of-the-other. Translated by Michael B. Smith and Barbara Harshav. New York: Cambridge University Press, 1998.

Lowith, Karl. Martin Heidegger and European Nihilism. Edited by Richard Wolin. Translated by Gary Steiner. New York: Columbia University Press, 1995.

Macierowski, E.M. Thomas Aquinas's Earliest Treatment of the Divine Essence. Binghamton, NY: Global Publications, 1998.

Martin, C.J.F. An Introduction to Medieval Philosophy. Edinburgh: Edinburgh University Press, 1997.

McGee, Glenn, ed. Pragmatic Bioethics. Nashville: Vanderbilt University Press, 1999.

Miklowitz, Paul S. Metaphysics to Metafictions: Hegel, Nietzsche, and the End of Philosophy. Albany: State University of New York, 1998.

Millgram, Elijah. Practical Induction. Cambridge: Harvard University Press, 1997.

Misak, C.J. Verificationism. New York: Routledge, 1996.

Murray, Patrick, ed. Reflections on Commercial Life: An Anthology of Classic Texts from Plato to the Present. New York: Routledge, 1997.

Plato. Plato: The Statesman. Edited by Julia Annas. New York: Canbridge University, 1995. 
Popper, Sir Karl. The Myth of the Framework. New York: Routledge, 1996.

Rutherford, Donald. Leibniz and the Rational Order of Nature. New York: Cambridge University Press, 1995.

Saatkamp, Jr., Herman J. Rorty and Pragmatism: The Philosopher Responds to His Critics. Nashville: Vanderbilt University Press, 1995.

Sallis, John. Double Truth. New York: Suny Press, 1995.

Santayana, George. The Birth of Reason and Other Essays. New York: Columbia University Press, 1968; 1995.

Savellos, Elias, ed. Supervenience: New Essays. Cambridge: Cambridge University Press, 1995.

Scharff, Robert C. Comte After Positivism. New York: Cambridge University Press, 1995.

Scott, Charles E. On the Advantages and Disadvantages of Ethics and Politics, Indiana: Indiana University Press, 1996.

Scott, Dominic. Recollection and Experience: Plato's Theory of Learning and lts Successors. Cambridge: Press Syndicate of the University of Cambridge, 1995.

Spinner, Jeff. The Botundaries of Citizenship. Maryland: Johns Hopkins, 1994.

Stewart, Arthur Franklin. Elements of Knowledge: Pragmatism, Logic and Inquiry. Nashville: Vanderbilt University Press, 1998.

Sugar, Peter F. and Ivo John Lederer. Nationalism in Eastern Europe, 3d ed. Seattle: University of Washington Press, 1994.

Tennant, Neil. Edits. New York: Columbia University Press, 1994.

Toddington, Stuart. Rationality, Social Action and Moral Judgment. New York: Columbia University Press, 1994. 
Trey, George. Solidarity and Difference: The Politics of Enlightenment in the Aftermath of Modernity. Albany: State University of New York Press, 1998.

Volk, Tyler. Metapatterns: Across Space, Time, and Mind. New York: Columbia University Press, 1995.

Walsh, W.H. Kant's Criticism of Metaphysics. Edinburgh: Edinburgh University Press, 1971; 1997.

Weinreb, Lloyd L. Oedipus at Fenway Park: What Rights Are and Why There are Any. Cambridge, MA: Harvard University Press, 1994.

Wilson, Robert. Cartesian Psychology and Physical Minds: Individualism and the Sciences of the Mind. New York: Cambridge University Press, 1995.

Wrong, Dennis H. The Problem of Order: What Unites and Divides Society, New York: The Free Press, 1994. 